\title{
ARTÍCULOS
}

\section{TRANSPARENCY AND ACCESS TO INFORMATION ON RESEARCH PROJECTS IN SPANISH PUBLIC UNIVERSITIES}

\author{
Transparencia y acceso a la información sobre los \\ proyectos de investigación en las universidades \\ públicas españolas
}

Ana-Reyes Pacios, Marina Vianello-Osti and Blanca Rodríguez-Bravo

Nota: Este artículo se puede leer en español en:

http://recyt.fecyt.es/index.php/EPI/article/view/52885/31995
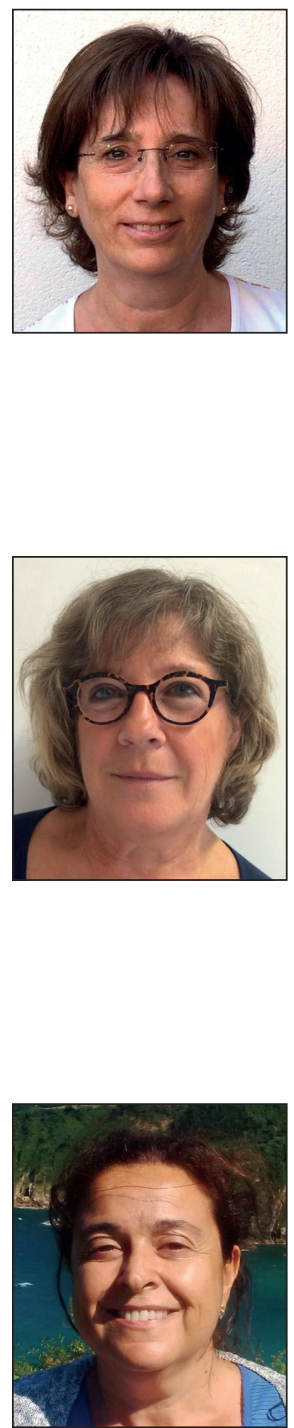

Ana-Reyes Pacios, PhD in philosophy from the University of Leon, Spain, is associate professor at the Library and Information Science and Documentation Department of Carlos III University, Madrid, since 1992. She teaches library management, resource management (human, library collection, financial, and economics), administration and management techniques, and other related subjects in courses leading to undergraduate and graduate degrees in library and documentation sciences. Her main line of research is management functions and techniques as applied to libraries (evaluation, quality, planning, and marketing). Author and co-author of various works published in both national and international journals (Library management, Library review, Libri, The electronic library, Interlending \& document supply, Performance measurement and metrics, etc.). http://orcid.org/0000-0003-2887-882X

Universidad Carlos III de Madrid. Departamento de Biblioteconomía y Documentación Madrid, 126-128. 28903 Getafe (Madrid), España areyes@bib.uc3m.es

Marina Vianello-Osti has a bachelor's of lettere italiane from Foscari University of Venice, in philology from the Complutense University of Madrid, and a PhD in documentation from the Carlos III University of Madrid (UC3M). She has been manager of the documentation center of the Institute of Demography of CSIC. Since 1996 she has been a member of the Department of Library and Information Science at the UC3M where she currently teaches courses in history, document analysis, and description of the ancient book. Her research focuses on history of literacy, knowledge organization, content analysis, hypertext, and usability. She has participated in conferences and has publications in journals and monographs.

http://orcid.org/orcid.org/0000-0002-8745-3947

Universidad Carlos III de Madrid. Departamento de Biblioteconomía y Documentación Madrid, 126-128. 28903 Getafe (Madrid), España mvianell@bib.uc3m.es

Blanca Rodríguez-Bravo, PhD in history from the University of Leon, Spain, is currently associate professor of library and information science at the Department of Documentary and Cultural Heritage of the University of Leon, where she is chair of the Condor Group (Organizing and use of digital content), which conducts research on knowledge organization, collection development, and usage of electronic journals. She teaches courses on authority control, knowledge organization, and scientific communication. She is the author of three monographs and co-author of another 10. In addition, she has approximately 60 articles in international and national journals. She has been head of 10 research projects and has participated in another six.

http://orcid.org/000-0002-9476-7602

Universidad de León, Facultad de Filosofía y Letras Departamento de Patrimonio Artístico y Documental. Área de Biblioteconomía y Documentación Campus de Vegazana, s/n. 24071 León, España blanca.rodriguez@unileon.es 


\begin{abstract}
In the framework of Spain's Transparency Act of 2013, an analysis is conducted of the information on research projects headed or participated in by Spanish public university teaching staff and funded by public institutions and bodies. The aims are to ascertain whether this information is associated with and published on transparency portals and to determine its typology and characteristics. The analysis covers portals and websites, access points and the type of information furnished. Although universities comply with the transparency obligations laid down in the act, the information on research projects freely available is not individualised and only rarely matched to results (such as articles, patents or conference communications), particulars that would not only encourage knowledge sharing, but enhance the credibility of and trust in research funding.
\end{abstract}

\title{
Keywords
}

Transparency; Accountability; Research projects; Spanish public universities.

\section{Resumen}

En el marco de la aplicación de la Ley de transparencia española del 2013, se analiza la información relacionada con los proyectos de investigación de las universidades públicas españolas que lidera y en los que participa su profesorado, financiados por instituciones y organismos públicos. Se pretende conocer si esta información se asocia y ubica en los portales de transparencia, así como su tipología y características. Para ello se analizan los portales, los puntos de acceso y el tipo de información que proporcionan. Aunque las universidades se muestran transparentes respondiendo a las obligaciones que establece la Ley, la información que tienen en libre acceso sobre los proyectos de investigación no está individualizada y raramente se vincula con los resultados obtenidos (artículos, patentes, ponencias, etc.) lo que permitiría compartir conocimiento, además de sumar credibilidad y confianza en la financiación de las investigaciones.

\section{Palabras clave}

Transparencia; Rendición de cuentas; Proyectos de investigación; Universidades públicas españolas.

Pacios, Ana-Reyes; Vianello-Osti, Marina; Rodríguez-Bravo, Blanca (2016). "Transparency and access to information on research projects in Spanish public universities". El profesional de la información, v. 25, n. 5, pp. 721-729.

https://doi.org/10.3145/epi.2016.sep.02

\section{Introduction}

Society is witnessing a persistent and reiterative use of the words 'transparency' and 'accountability'. This may be closely associated with the heightening of moral, economic, and social concerns brought on by the financial crisis that has affected much of the world since 2008. As a result, in Spain legislation has been enacted on information transparency and accessibility, despite previously existing specific sectoral rules, in an attempt to enhance and reinforce both. Questioned, criticized, and intensely debated (MenéndezMenéndez, 2012), Act 19/2013 on Transparency, access to public information and good governance (hereafter the Transparency act) (España, 2013) went into effect in 2014. According to the text, it is 'an optimal tool for controlling the management and use of public resources'.

Transparency and accountability go hand-in-hand with the former, which is a pre-requisite to the latter (Heeks, 2008). Nonetheless, as Fox (2007) notes, transparency does not necessarily lead to accountability; it also depends on institutions ensuring the presence of both. In an analysis of these notions and their application over time, Neyland (2007) concluded that when transparency requirements are established, organizations tend to generate new or reformatted information specifically designed to comply with the transparency and accountability criteria in place. The contention, apparently, is that instituting requirements does not always lead to the aim pursued.
Transparency and accountability are associated with the obligation incumbent upon policy makers to inform their constituents on how power is wielded (Mathisson; Ross, 2002, p. 97). That translates into disclosing how public resources are used by allowing access to information on decisionmaking and fostering open dialogue and debate to explain and justify such decisions (Mulgan, 2000). Merely making information available does not, therefore, suffice to ensure transparency. The information furnished must be significant and accessible, presented in suitable language and format, and understandable to all stakeholders. It must also be timely, accurate, and publicly available long enough for its analysis and assessment by the parties concerned, who must commit to its reusability and unaltered use.

One common initiative stemming from the application of Spain's Transparency Act is the creation of 'transparency portals' by a wide range of institutions. These meet the 'active public disclosure' provision laid down in Chapter II, Title I (Arts. 5-11) of the act, requiring awarders and awardees to publish information on assistance and subsidies. Government bodies make public information accessible on these platforms. The aim is to provide citizens with clear information on how funds are used, the subsidies granted, and their beneficiaries.

The scope of the act is wide-ranging, covering all public bodies, including public universities. In Chapter II on active public disclosure it lays down a series of obligations, one 
of which is the dissemination of certain types of economic, budgetary, and statistical information. Spanish universities' transparency portals consequently aim to furnish information on their management and results, affording access to public data.

Under the act, given their particular significance and as funding recipients, public universities are bound to comply with specific active disclosure requirements. They receive subsidies from international, European, national, regional and local bodies, in addition to university programs. The drastic reduction in the resources provided by Spain's national government for R\&D+I (research, development, and innovation) has led to a critical situation. Significantly, after having risen from $€ 31,950$ in 2002 to $€ 41,070$ in 2009, the budget per full-time researcher equivalent was cut back to $€ 22,560$ in 2013 . Some ministerial programs have disappeared, while the funds for regional governments and the $\mathrm{Na}$ tional Research Council (Spanish initials, CSIC) have plunged (Molero; De-Nó, 2013). Such a decline in funds has intensified competition and the need to ensure that they are effectively applied and the results published, all of which calls for greater transparency.

Merely making information available does not, therefore, suffice to ensure transparency. The information furnished must be significant and accessible, presented in suitable language and format, and understandable to all stakeholders

Certain institutions, such as the Carlos III Institute of Health, which unveiled its Health Research Found (Fondo de Investigación en Salud, FIS) website in September 2015 (Mineco, 2015), are making meaningful strides in this respect. https://portalfis.isciii.es

This online tool groups 1,300 publicly funded research projects on health conducted over the last three years, making the research accessible to citizens as well as other researchers. The site specifies project objectives, the institution where it was conducted, the funding received, and the name of the head researcher.

Spanish universities' research support units and services, departments, and institutes publish the funding awarded to their teaching staff under competitive procedures. The manner in which they do so varies (research memoranda, 'transparency' portals, the Universitas XXI academic management system, project catalogs, scientific dissemination units).

http://www.ocu.es/productos/universitas-xxi-academico

When available, that information tends to be scattered, at times duplicated and not easily found, raising the questions that are addressed in the present study.

- Do universities associate information on research projects with transparency requirements?

- What type of information on research projects is provided by Spanish public universities?
- Can the information be regarded as 'transparent' when applying the specific requirements laid down in the Transparency Act?

This study aims to determine whether public universities provide transparent access to information on publicly funded research projects headed or participated in by their academics. Based on the findings of the analysis conducted, a proposal is put forward about the information that should be disclosed in order to be 'transparent'.

\section{Review of the literature}

Spain's R\&D investment has been regarded as scant. While R\&D spending was clearly insufficient in 2007, and much lower than in neighboring countries (Hernández-Rubio, 2007), the downward trend recorded from 2008 onward made matters worse. According to an EAE Business School (2015) report, €13 bn were invested in $R \& D+I$ in Spain in 2013 , down by $3 \%$ from the preceding year and a cumulative $11 \%$ from 2008.

Private enterprise accounts for $53 \%$ of Spanish investment in $R \& D+I$, followed by higher education institutions with $28 \%$, and public bodies with $19 \%$. Nonetheless, total research and development (R\&D) spending per capita in Spain in 2013 amounted to $€ 279.30,2.34 \%$ less than in the year before, a moderate decline compared to previous years. Such figures reveal the critical situation in recent years and the need for efficient management of the waning resources earmarked for research projects. That in turn calls for transparency and accountability of the award and use of funds.

The accessibility of information on its research projects is a way of disseminating knowledge on the areas under study, the staff involved, the time invested, and the results

Although many studies have been conducted on transparency and its effects, its application to research projects has been analyzed much less thoroughly. Searches for papers in the literature focusing on transparency in connection with research projects yields few results. However, studies on transparency in universities have been conducted. Some focus on 'accountability', viewed as a management responsibility to the governments on which they depend (Nelson; Banks; Fisher, 2003). Others relate transparency to the measurement of intellectual capital (Fazlagic, 2005). In that vein, a few papers have highlighted the utility of measuring intellectual capital to improve research management and contribute to a comparative analysis of universities (Sánchez; Elena, 2006).

From the standpoint of knowledge management, some reports contain information intended to enhance science and technology system transparency. The aim is to afford a more accurate and detailed understanding of some of the basic aspects of the generation, dissemination, and use of 

BARCELONA

Català Español English 中文 Corce ESTUDIOS Y DOCENCIA LA UNIVERSIDAD INVESTIGACION

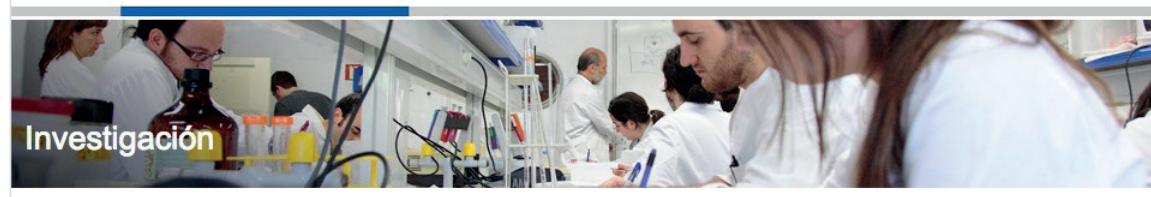

- Investigación Investigación en la UB Institutos y centros
de investigación Observatorios centros de Grupos de Grupos de Proyectos - Hospitales Infraestructuras de - Infraes
apoyo Ética e investigación Investigación en abierto Innovación y transferencia del conocimiento Doctorado HR Excellence in Rexcellonction
UNIVERSITAT ${ }_{D E}$

\section{Buscador de proyectos} empresss, la UB consigue anualmente unos ingresos de más de 76 millones de euros por esta actividad.

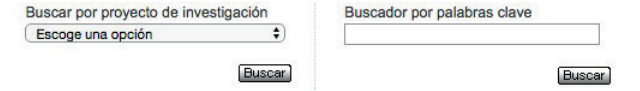

Buscador de proyectos por orden alfabético

A $|B| C|D| E|F| G|H| I|J| K|L| M|N| O|P| Q|R| S|T| U|V| W|X| Y|Z|$ Todos

1. ANALLISI DE LA BASE DE DADES 'OCUPADORS PRIVATS': PROPOSTA D'ANÄLISIS ESTADISTICA AVANÇADA DE LES DADES DERIVADES DE L'ESTUDI 'OCUPABILITATI COMPETENNCIES DELS GRADUATS RECENTS: L'OPINIO D'EMPRESES I INSTITUCIONS, PRINCIPALS RESULTATS DE L'ESTUDI D'OCUPADORS 2014

3. ANALLISI DE LA BASE DE DADES 'CENTRES EDUCATIUS' CAP A UN MODEL DE FORMACIÓ INTEGRAL DELS PROFESSIONALS DE LA DOCĖNCIA DES DE LA GESTIÓ DE LA
La actividad investigadora de la UB lidera la producción cientifica del Estado español. Con más de 700 proyectos nacionales compelitivos en curso, casi 70 de europeos i más de 750 contratos con CARRERA PROFESSIONAL

Research projects. Universitat de Barcelona

http://www.ub.edu/dyn/cms/continguts_es/recerca_innovacio/recerca_a_la_UB/projectes/index.html

Cavanna; Barrio, 2015) fall under this category. As the authors note, their reports have served to increase web-based transparency and accountability, raising society's trust in and support for academic institutions. The areas for determining transparency found to be most wanting were results and economic information. The latter was judged to be clearly insufficient in the first report (Barrio; Martín-Cavanna, 2012). Despite the substantial improvement detected in the second (Barrio; Martín-Cavanna, 2013), continual improvements were called for in accountability, a factor regarded as particularly significant, given that the institutions involved are funded primarily with public money. In their last paper, the authors reported that transparency had improved. The number of universities regarded as 'transparent', based on 26 indicators and the criteria defined (visibility, accessibility, recentness, and comprehensiveness) rose from none (Barrio; Martín-Cavanna, 2012) to knowledge in certain autonomous regions (Comunidad de Madrid, 2002). That notwithstanding, the present authors deem that the universities themselves, which have such information, are better positioned than any other entity to share the knowledge and intellectual capital generated by the research to which they devote much of their endeavors. In addition to contributing to an institution's transparency, the accessibility of information on its research projects is a way of disseminating knowledge on the areas under study, the staff involved, the time invested, and the results. It also furnishes replies to questions concerning project management posed by those beginning to undertake such tasks. Making this information available indisputably forms part of knowledge management, favors new researchers' learning process and constitutes a ready method for associating a project with its results.

Open science furthers a globalized knowledge society. The epicenter of the paradigms emerging in science 2.0 lies in collaboration, web-based communication platforms, and more open and democratic academic communication practices (Shneiderman, 2008). This new approach requires greater transparency, knowledge dissemination, and transfer to society in general and academia and enterprise in particular. With it, science will serve as a point of departure for progress and innovation genuinely benefitting citizens, who must necessarily back academic activity (Veletsianos; Kimmons, 2012).

Other authors have defined criteria on which to determine the degree of university transparency (Maldonado-Radillo, 2013). Three successive studies on transparency in Spanish universities (Barrio; Martín-Cavanna, 2012; 2013; Martín-
16 (Martín-Cavanna; Barrio, 2015), with $80 \%$ of the public universities and $31 \%$ of the private institutions attaining optimal transparency. More specifically, the authors established the following item under the indicator 'Results':

"The university publishes the key results of its professors' research endeavour: theses and papers published, patents and so on" (Martín-Cavanna; Barrio, 2015).

No mention is made of research projects.

\section{Although many studies have been con- ducted on transparency and its effects, its application to research projects has been analyzed much less thoroughly}

Two studies relevant to the present subject, focusing specifically on the funds earmarked for research projects, were authored by Mangas-Martín (2010; 2011). In both studies the author criticizes the questionable practices deployed in research project selection, claiming that the respective funding was wasted. Referring to research projects on legal affairs, she contends that

'the vast majority... are no more than show, dealing with irrelevant and overworked subjects... most projects neither produce results nor inspire further research' (Mangas-Martín, 2011).

Such assertions justify the need for transparency in research projects, primarily with regards to results. 
Spain's Act on Science, Technology, and Innovation (2011) alludes on eight occasions to the principle of transparency that should govern the implementation of the country's science, technology, and innovation system. On four of those occasions the word transparency is found in conjunction with 'accountability'. Funding agents are explicitly required to

"conduct their activity in accordance with the principles of independence, transparency, accountability, effectiveness and management efficiency" (Mineco, 2011, p. 25).

One standard practice of financial agents is to require head researchers to draw up a final memorandum or report specifying the results. However, such memoranda are not normally available to the public. One exception is the Cordis database, the European Commission's primary public repository and portal for disseminating information on all EU-funded research projects funded and their results, in the broadest sense (European Commission, 2016).

\section{Method}

The methods used to attain the objective pursued in this study were divided into the following phases and entailed the application of the criteria set out below.

1) The 49 universities included in the sample were drawn from the 50 public institutions listed on the CRUE (Spanish initials for Conference of Spanish university rectors) website, all of which are dependent upon their respective regional governments for funding. Menéndez Pelayo International University was excluded because it has no academic staff of its own, inasmuch as research projects are applied for by each university's professors.

http://www.crue.org/universidades/Paginas/default.aspx? Mobile $=0$

2) The possible points on university websites for accessing information on research projects were chosen, with the ideal being the existence of a single access point for the transparency portal. Where a university had no transparency portal or where it contained no information on projects, other possible links listed on its main website were analyzed. In particular, focus was placed on links to 'Research' found on many Spanish universities' websites.

3) The access points and content on the universities' websites and portals were searched and analyzed in November 2015 using the criteria adopted by Barrio y Martín-Cavanna (2015). Such criteria were based on the manner in which information is be published, according to Art. 5 of the Transparency Act.

- Visibility was regarded to be good when the content was prominently exhibited on the website and readily identifiable. On occasion, the content was present in the portal but not readily visible because the path to reach it was particularly complex.

- A second major element considered was accessibility: queries were not to be subject to permission or registration, and identification and searches were to be userfriendly.

- Information had to be up-to-date. The information requested was to refer to the last fiscal period officially ended, in this case 2014.

- The fourth and last element was comprehensiveness, defined to mean that the information was complete and exhaustive. These criteria were not met when the information on a given item was only partial. Information on some but not all departments' research projects would not suffice, for instance.

4) A spreadsheet was created on which all the data for each university were included as its website and portal were analyzed.

5) The findings were analyzed and the respective conclusions drawn.

\section{Results}

Prior to embarking on any casuistic discussion of the data on research projects furnished by universities and where on their respective websites they are found, it should be said that $44(89.8 \%)$ of the 49 universities analyzed had a transparency portal. In 41 (83.7\%) cases, the link to the portal was located on the university's home page, although it did

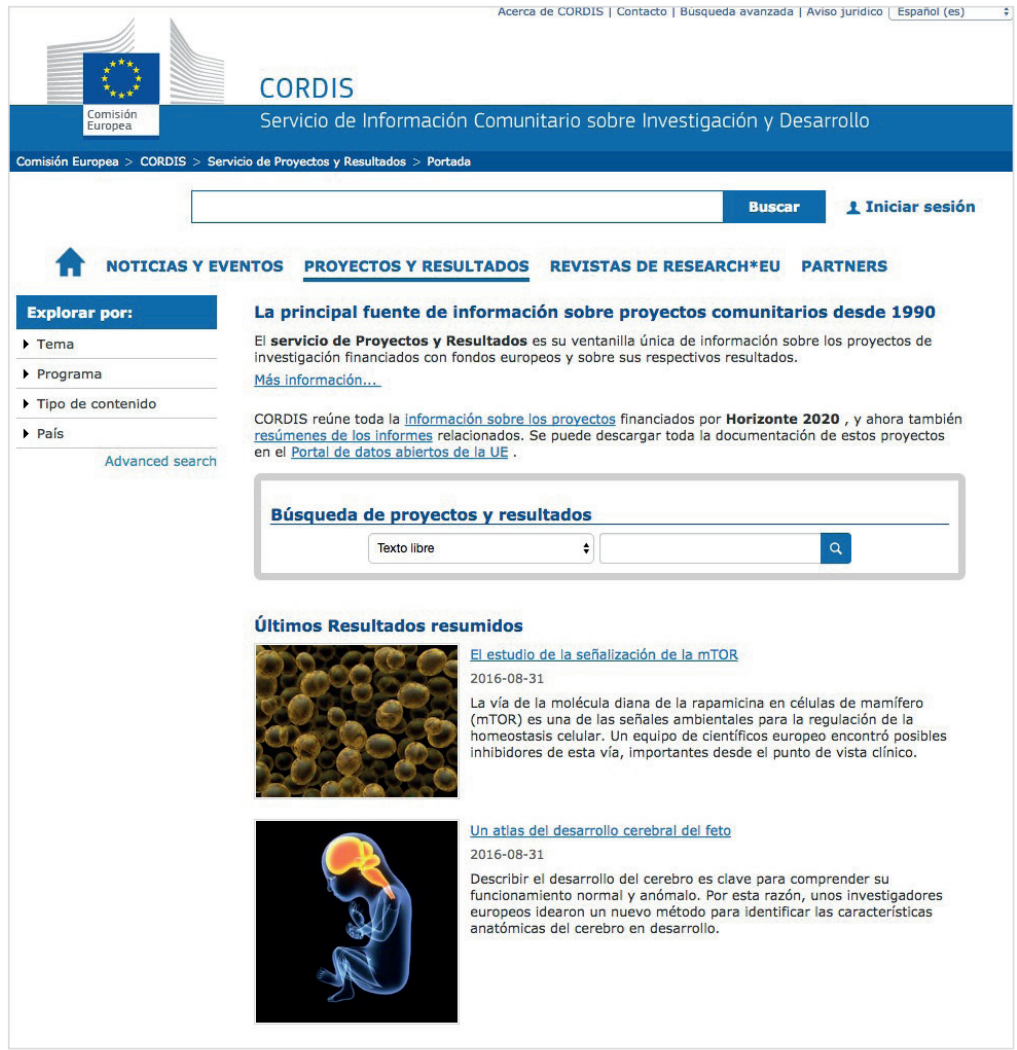

Community Research and Development Information Service (Cordis) http://cordis.europa.eu/projects/home_es.html 
not always conform to the principles of visibility and accessibility. Significant differences were observed among universities' websites, from those that clearly identified the link on the right- or left-hand panels under the word 'Transparency' to those in which it was barely visible in small print at the bottom of the page.

\subsection{Transparency portal with information on re- search projects}

Some information on research projects could be found in 34 of the 44 transparency portals (69.3\% of the total sample). The name of the link varied, although many shared certain tags: research, results, and statistics were the three most often used. Ten ( $20.4 \%$ of the total sample) of the aforementioned 34 transparency portals had a single access point for all projects, eluding the need to jump from page to page and link to link to find the information.

Only 12 of the 49 universities (24.4\%) furnished individualized information on each project, which was not always uniform or complete

Of the five (10.2\% of the total sample) universities with no transparency portal, two furnished no information on projects, while three had a link on their home page entitled 'Research' from which some information on projects could be accessed. One furnished global statistical information, while the other two had search engines with lookup field options to locate project details. The latter approach was observed at the Polytechnical University of Madrid and the University of Santiago de Compostela.

\subsection{Type of information available on research pro- jects}

The type of data identified on the 34 transparency portals from which queries on information about research projects could be posed is discussed below.

- In 32 cases ( $65.3 \%$ of the total sample), the information was confined to global data, such as total funding raised in European or national competitions (in keeping with Art.
83 of Constitutional act 6/2001 on Universities) and the total number of projects in each category. That information was found on the pages on university statistics in 21 cases ( $42.8 \%$ of the total sample), the university's research memorandum in seven ( $14.2 \%$ of the total sample), and less commonly in other files such as specific departments' research memoranda providing information on research teams.

- Only 12 of the 49 universities (24.4\%) furnished individualized information on each project, which was not always uniform or complete. Access vehicles varied, from yearly research memoranda for the university as a whole, with some details on each department's projects, to pages listing statistics, research teams, and the like. Of these 12 universities, ideal access, i.e., in the form of a catalog or database with a number of search options, was provided by seven (Polytechnical University of Catalonia and the universities of Lleida, Barcelona, Murcia, Extremadura, Baleares, and Alicante: $14.2 \%$ of the total sample) (table 1). This approach was deemed to be the most transparent, for it delivered significant data on each project, such as head researcher, funding body, and researchers participating.

\subsection{Exhaustive information on each project}

The fullest information on projects was found not on the transparency portals but on certain research teams' webpages, in turn generally accessed from the respective university department's website. This was not always the case even within a given university, however, for not all research teams had webpages with a standardized format. Moreover, not all the teams with pages maintained them in the same manner, with significant differences in the type of information that was routinely updated. In addition, visibility was low, with the exception of four universities, when the links to research teams' information were not found on the transparency portals but at the end of a long path across the respective department's website. The link entitled 'Research' on universities' home pages provided another route to that information. The research teams with the best webpages, in terms of information accessibility, listed the funded projects they were working on or had worked on in recent years. A few good examples were found at the Carlos III University, Pompeu Fabra University,

Table 1. Access to and type of information on Spanish public universities' research projects

\begin{tabular}{|c|c|c|c|c|}
\hline $\begin{array}{c}\text { N. of public universities } \\
\text { analyzed }\end{array}$ & $\begin{array}{c}\text { Transparency portal in } \\
\text { place }\end{array}$ & $\begin{array}{l}\text { Access to information on } \\
\text { projects provided }\end{array}$ & Type of information & $\begin{array}{c}\text { Database or catalog } \\
\text { in place }\end{array}$ \\
\hline \multirow{7}{*}{49} & \multirow{4}{*}{$\begin{array}{c}44 \\
\text { (41 with link on home page) }\end{array}$} & \multirow{2}{*}{$\begin{array}{c}34 \\
\text { (10 with a centralized access } \\
\text { point) }\end{array}$} & 32 (global) & \\
\hline & & & $\begin{array}{c}12 \text { (individualized for each } \\
\text { project) }\end{array}$ & 7 \\
\hline & & \multicolumn{3}{|c|}{ No access to information on projects } \\
\hline & & \multicolumn{3}{|c|}{10} \\
\hline & No transparency portal & & & \\
\hline & \multirow{2}{*}{5} & \multicolumn{3}{|c|}{3 (with 'Research' link and some information) } \\
\hline & & \multicolumn{3}{|c|}{2 (with no information) } \\
\hline
\end{tabular}


Polytechnical University of Catalonia, and the Universities of Barcelona and Vigo. More examples may exist, however, since the search aimed not to locate research teams but to access information on research projects from the transparency portal.

http://atlanttic.uvigo.es/el-centro/atlanttic-de-un-vistazo

The ideal (and recommended) vehicle for accessing information on projects is a single centralized point with lookup field options (such as project director, subject, or funding body)

Despite these good practices, it proved difficult to find project-associated results, such as the type of publications. That information was located for only one university and for European projects only because it was linked to the Cordis database. Cordis is a good model for universities to follow when providing information on projects, for all the European Commission's information on EU-funded projects throughout their life cycle can be searched and queried:

- subsidy details;

- funding;

- participants;

- summary reports on the project itself;

- (multi-lingual) summaries of the latest findings; and

- links to specific publications and other documents.

The abridged results constitute a (multi-lingual) summary of project findings in accessible language designed to favor their use. This example for universities to follow is not new: data on Cordis projects date from 1990 and cover FP7, FP6, FP5 and even earlier EU framework programs. Inclusion of the Horizon 2020 projects is likewise envisaged.

Universities' failure to furnish information on results is difficult to justify in terms of the factors limiting the right to access information laid down in the Transparency Act (Chapter III, Art. 14): professional secrecy, intellectual and industrial property, and protection of personal data. After projects are finalized and sufficient time lapses to elude intellectual property-related risks, however, the associated results should be disclosed (patents, publications, and so on). Nonetheless, the source of funding can often only be identified by mining the databases to see whether it is cited by the author or authors in their papers.

The items found on the websites containing information on research projects and the percentage of sites giving the respective data are listed in table 2 . Full information on all the items was not furnished for any of the projects. The lack of data on research-related results (such as publications, patents and, congress papers) was particularly striking, because they are used to determine actual performance.

\section{Conclusions}

The following conclusions can be drawn from the analysis of the information on research projects found on universities' transparency portals.
- The existence of portals stands as proof that most universities associate freedom of information with the right of access and their obligation to make data on university management and results available to anyone interested. They are working on improving these portals to furnish clearer information on their activity, sharing knowledge with citizens to further their participation in society, and afford them greater control over public affairs.

- In some cases transparency portals must improve their visibility and accessibility, for the respective link is often located on scantly visible areas of the home page or elsewhere, requiring users to jump from page to page.

- That some manner of information on research projects can be accessed from the transparency portal is an indication that universities regard it as a transparency-related item and in that respect they are Transparency Act-compliant. As beneficiaries of public subsidies and assistance, they furnish some information of this nature.

- The ideal (and recommended) vehicle for accessing information on projects is a single centralized point with lookup field options (such as project director, subject, or funding body) (table 2). That approach was identified for only a short number of universities that have opted to create a project database to simplify data search and retrieval. Nonetheless, the analysis of the cases identified revealed that not all fields are always covered, even though they constitute nearly all the formal features of a project. Even fields on results (such as articles and conference papers)

Table 2. Information on Spanish public universities' research projects: items and percentage of projects for which they are reported

\begin{tabular}{|l|c|}
\hline \multicolumn{1}{|c|}{ Item } & $\%$ \\
\hline Title & 71.4 \\
\hline Start date & 61.2 \\
\hline Head researcher & 57.1 \\
\hline End date & 57.1 \\
\hline Funding body & 55.1 \\
\hline Project code or reference number & 44.9 \\
\hline Total grant & 26.5 \\
\hline Participants' names & 20.4 \\
\hline Institute implementing the project & 16.3 \\
\hline Program & 14.3 \\
\hline Plan & 14.3 \\
\hline Scope & 12.2 \\
\hline Name of research team & 12.2 \\
\hline Year of competition & 12.2 \\
\hline Abstract & 8.2 \\
\hline Participating institutions & 8.2 \\
\hline Number of researchers & 6.1 \\
\hline Keywords & 2.1 \\
\hline Purpose & 4.1 \\
\hline Unesco code & 2 \\
\hline Project URL & 2 \\
\hline Competition & 2.1 \\
\hline Results & 2.3 \\
\hline
\end{tabular}


were found to be missing. All project directors should commit to furnishing content under all fields to ensure that the information listed is as full and uniform as possible.

- Not all transparency portals carry exhaustive information on research projects. Some universities with no portal furnish more information than those that have one but fail to use it for this purpose. The fullest information is contained on research teams' own webpages.

- In most cases the information on research projects accessible from transparency portals is of no greater value than the same information included under headings (such as research, university facts and figures, or memoranda) in 'traditional' websites. Transparency portals often simply furnish a link to existing webpages or files. While that heightens visibility, it neither supplements information nor has any impact on its quality. In the present authors' opinion, more than mere sites with links to access otherwise scattered information, transparency portals should constitute an opportunity to standardize data presentation, make information readily accessible (through databases) and ensure its reusability. Moreover, project results (publications generated), which are not generally furnished, should be included.

Not all transparency portals carry exhaustive information on research projects. Some universities with no portal furnish more information than those that have one but fail to use it for this purpose

- Although universities can be said to be transparent insofar as they provide free access to information on research projects in keeping with Transparency Act requirements (as a rule, global data on funding), they rarely match such information to results. Establishing relationships of this kind would indisputably encourage knowledge sharing while enhancing the credibility of and trust in research funding. While data on scientific output is usually processed with particular care by universities, this type of information is not furnished in their portals and websites on a project-by-project basis.

- Relating projects to their results is yet another step toward accountability to encourage responsibility in the use of public funds. The excellence of a result is best achieved when it is explained outside the realm in which it was generated.

\section{References}

Barrio, Esther; Martín-Cavanna, Javier (2012). Examen de transparencia. Informe de transparencia en la web de las universidades públicas españolas. Fundación Compromiso y Transparencia.

http://goo.gl/f5tXPl

Barrio, Esther; Martín-Cavanna, Javier (2013). Examen de transparencia. Informe de transparencia en la web de las universidades públicas españolas 2012. Fundación Compromiso y Transparencia.

http://www.compromisoempresarial.com/wp-content/ uploads/InformeUniversidad2012.pdf

Comunidad de Madrid (2002). Capital intelectual y producción científica. Madrid: Dirección General de Investigación ISBN: 8445122339

https://www.madrimasd.org/informacionidi/biblioteca/ publicacion/doc/Libro_12completo.pdf

EAE Business School (2015). La inversión en I+D+l 2015. https://www.madrimasd.org/empleo/documentos/doc/EAE_ Business_School_La_inversion_en_I+D+i_en_Espana_2015.pdf

España (2001). "Ley orgánica 6/2001, de 21 de diciembre, de Universidades". BOE, n. 307, 24 de diciembre.

https://www.boe.es/buscar/act.php?id=BOE-A-2001-24515

España (2011). “Ley 14/2011, de 1 de junio de la Ciencia, la tecnología y la innovación". BOE, n. 131, 2 de junio. https://www.boe.es/buscar/act.php?id=BOE-A-2011-9617

España (2013). “Ley 19/2013, de 9 de diciembre, de Transparencia, acceso a la información pública y buen gobierno". $B O E$, n. 295, 10 de diciembre. Texto consolidado.

https://www.boe.es/buscar/act.php?id=BOE-A-2013-12887 
European Commission (2016). Cordis (Community Research and Development Information Service).

http://cordis.europa.eu/home_en.html

Fazlagic, Amir (2005). "Measuring the intelectual capital of a university". En: Trends in the management of human resources in higher education.

https://www.oecd.org/edu/imhe/35322785.pdf

Fox, Jonathan (2007). "The uncertain relationship between transparency and accountability". Development in practice, v. 17, n. $4-5$, p. 663-671.

http://goo.gl/KhM5GJ

https://doi.org/10.1080/09614520701469955

Heeks, Richard (2008). eGovernment for development. Information exchange. Web page project coordinated by the University of Manchester's Institute for Development Policy and Management.

http://www.egov4dev.org/transparency/definitions. shtml\#accountability

Hernández-Rubio, Carolina (2007). "La inversión en I+D+i en España: un análisis comparativo". Anuario jurídico y económico escurialense, $\mathrm{XL}$, pp. 569-590.

https://goo.gl/uNwAlY

Maldonado-Radillo, Sonia-Elizabeth; Alcántar-Enríquez, Víctor-Manuel; García-Rivera, Blanca-Rosa; Ramírez-Barón, María-Concepción (2013). "La transparencia de las instituciones públicas de educación superior del Noroeste de México". Revista internacional administración y finanzas, v. 6, n. 4, pp. 73-88.

http://papers.ssrn.com/sol3/papers.cfm?abstract_id=2157151

Mangas-Martín, Araceli (2010). “Dispendio universitario en proyectos fantasma". El mundo, 2 de marzo.

http://www.elmundo.es/opinion/tribuna-libre/2010/03/22936078. html

Mangas-Martín, Araceli (2011) "La evaluación de la investigación jurídica en España". El cronista del estado social y democrático de derecho, n. 23, pp. 60-71.

http://eprints.sim.ucm.es/30443

Martín-Cavanna, Javier; Barrio, Esther (2015). Examen de transparencia. Informe de transparencia voluntaria en la web de las universidades españolas 2014. Fundación Compromiso y Transparencia.

https://gpaq.upc.edu/ranquings/doc/articles/Informetransparencia-universidades-2014.pdf

Mathison, Sandra; Ross, E. Wayne (2002). "The hegemony of accountability in schools and universities". Workplace, v. 9, pp. 88-102.

https://www.academia.edu/573278/The_Hegemony_of_ Accountability_in_Schools_and_Universities

Menéndez-Menéndez, Adolfo (2012). “Una administración pública transparente, responsable y eficaz". Actualidad jurídica Uría Menéndez, n. extra 1, pp. 73-79.

http://www.uria.com/documentos/publicaciones/3605/ documento/a7.pdf?id $=4412$

Ministerio de Economía y Competitividad (2015). La secretaria de Estado de I+D+i presenta el portal 'Fondo de investigación en salud'.

http://goo.gl/JAl1xF

Molero, José; De-Nó, José (2013). Informe Cosce. Análisis de los recursos destinados a I+D+i (política de gasto 46) contenidos en los presupuestos generales del estado para el año 2013. Madrid: Cosce.

http://www.cosce.org/pdf/informeCOSCE_PGE2013.pdf

Mulgan, Richard (2000). "Accountability: an ever expanding concept?". Public administration, v. 78, n. 3, pp. 555-573. https://doi.org/10.1111/1467-9299.00218

Nelson, Morton; Banks, William; Fisher, James (2003). "Improved accountability disclosures by Canadian universities". Canadian accounting perspectives, v. 2, n. 1, pp. 77-107.

http://citeseerx.ist.psu.edu/viewdoc/download?doi=10.1.1. 199.2981\&rep=rep1\&type $=p d f$

Neylan, Daniel (2007). "Achieving transparency: The visible, invisible and divisible in academic accountability networks". Organization, v. 14, n. 4, pp. 499-516.

https://doi.org/10.1177/1350508407078050

Sánchez, María-Paloma; Elena, Susana (2006). “Intellectual capital in universities: Improving transparency and internal management". Journal of intellectual capital, v. 7, n. 4, pp. 529-548.

https://doi.org/10.1108/14691930610709158

Shneiderman, Ben (2008). “Science 2.0". Science, v. 319, pp. 1349-1350.

https://doi.org/10.1126/science.1153539

Veletsianos, George; Kimmons, Royce (2012). “Assumptions and challenges of open scholarship". The international review of research in open and distance learning, v. 13, n. 4, pp. 166-189.

http://www.irrodl.org/index.php/irrodl/article/view/1313
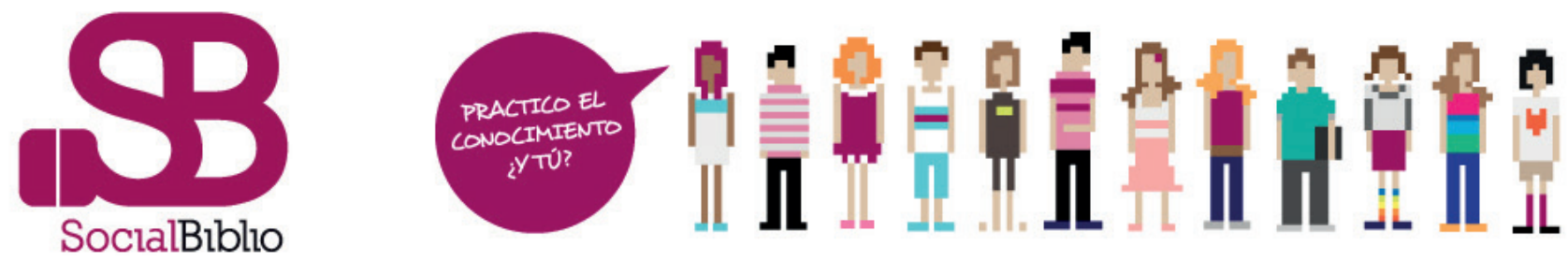